\title{
Distal renal tubular acidosis in primary Sjögren syndrome
}

\author{
Tim Both ${ }^{1 *}$, Ewout J Hoorn ${ }^{1}$, Zana Brkic ${ }^{2}$, Marjan A Versnel ${ }^{2}$, Jan AM van Laar ${ }^{1}$, P Martin van Hagen ${ }^{1}$, \\ Robert Zietse ${ }^{1}$, Paul LA van Daele ${ }^{1}$ \\ From 7th European Workshop on Immune-Mediated Inflammatory Diseases \\ Noordwijk aan Zee, the Netherlands. 28-30 November 2012
}

\section{Introduction}

Primary Sjögren syndrome (pSS) is a chronic inflammatory disorder characterized by lymphocytic infiltration of exocrine glands. pSS can also cause distal renal tubular acidosis (dRTA). dRTA is a disorder in which patients are unable to acidify their urine because of impaired hydrogen ion secretion in the collecting duct.

\section{Aim}

To determine the prevalence of dRTA in pSS using a urinary acidification test.

\section{Patients and methods}

$62 \mathrm{pSS}$ patients and 27 healthy controls participated in the study. After baseline measurements, both groups received a single administration of $40 \mathrm{mg}$ furosemide and $1 \mathrm{mg}$ fludrocortisone after which urine $\mathrm{pH}$ was measured hourly for six hours (Walsh et al., Kidney Int 2007). dRTA was initially defined as a failure to achieve a urine $\mathrm{pH}<5.3$.

\section{Results}

At baseline, pSS patients had a significantly higher urine $\mathrm{pH}(6.2 \pm 0.6$ vs. $5.8 \pm 0.7)$ and lower estimated ammonium secretion $(10 \pm 14$ vs. $25 \pm 23 \mathrm{mmol} / \mathrm{l})$ than controls ( $\mathrm{p}<0.01$ for both), already suggesting a subtle acidification defect in pSS. Only 4 pSS patients, however, had overt metabolic acidosis (serum bicarbonate $<21 \mathrm{mmol} / \mathrm{l}$ ). During the test, 24 pSS patients (39\%) failed to acidify their urine to a $\mathrm{pH}<5.3$.

Seven controls (26\%), however, were also unable to reach a urine $\mathrm{pH}<5.3(\mathrm{p}=0.3)$. Therefore, we believe a urine $\mathrm{pH}$ of 5.3 may not be sufficiently specific for

'Dept. of Internal Medicine, Erasmus MC, Rotterdam, The Netherlands Full list of author information is available at the end of the article diagnosing dRTA in pSS. All controls did reach a urine $\mathrm{pH}$ of 5.8 or lower during the test. Setting the threshold at this level, 7 patients with pSS (11\%) were diagnosed with dRTA.

\section{Conclusions}

The prevalence of dRTA in pSS is relatively high. A urinary acidification test is more sensitive to diagnose dRTA in pSS than serum bicarbonate, but the threshold for a positive test should be set at a urine $\mathrm{pH}$ of 5.8 instead of 5.3.

\section{Author details}

${ }^{1}$ Dept. of Internal Medicine, Erasmus MC, Rotterdam, The Netherlands.

${ }^{2}$ Dept. of Immunology, Erasmus MC, Rotterdam, The Netherlands.

Published: 28 November 2012

doi:10.1186/1479-5876-10-S3-P8

Cite this article as: Both et al:: Distal renal tubular acidosis in primary Sjögren syndrome. Journal of Translational Medicine 2012 10(Suppl 3):P8.

Submit your next manuscript to BioMed Central and take full advantage of:

- Convenient online submission

- Thorough peer review

- No space constraints or color figure charges

- Immediate publication on acceptance

- Inclusion in PubMed, CAS, Scopus and Google Scholar

- Research which is freely available for redistribution

Submit your manuscript at www.biomedcentral.com/submit
C Biomed Central

(c) 2012 Both et al; licensee BioMed Central Ltd. This is an Open Access article distributed under the terms of the Creative Commons Attribution License (http://creativecommons.org/licenses/by/2.0), which permits unrestricted use, distribution, and reproduction in any medium, provided the original work is properly cited. 